\title{
PENERAPAN STRATEGI PEMBELAJARAN KOOPERATIF TIPE COOPERATIVE SCRIPT PADA PERKULIAHAN PROGRAM LINIER UNTUK MENINGKATKAN AKTIVITAS DAN PRESTASI BELAJAR MAHASISWA SEMESTER IV PROGRAM STUDI PENDIDIKAN MATEMATIKA FKIP UNIVERSITAS MATARAM
}

\author{
Nani Kurniati, Sripatmi, Muhammad Turmuzi \\ ${ }^{1}$ Program Studi Pendidikan Matematika FKIP Universitas Mataram, Mataram, Indonesia \\ Email: sripatmi@unram.ac.id
}

\begin{abstract}
Abstrak: Penelitian ini dilatar belakangi dari pengalaman peneliti selama mengampu mata kuliah Program Linier terlihat bahwa aktivitas belajar mahasiswa masih kurang sehingga prestasinyapun tidak maksimal. Oleh sebab itu, tujuan dari penelitian ini adalah untuk meningkatkan aktivitas dan prestasi belajar mahasiswa semester IV program studi pendidikan matematika FKIP Universitas Mataram tahun akademik 2013/2014. Penelitian tindakan kelas ini dilakukan selama 3 siklus, hasil yang diperoleh pada masing - masing siklus adalah rata - rata hasil evaluasi 63,14, ketuntasan klasikal 67,65 \% dan kategori keaktifan cukup aktif dan aktif pada siklus I, rata - rata hasil evaluasi 75,74 , ketuntasan klasikal $100 \%$ dan kategori keaktifan aktif dan aktif pada siklus II, rata - rata hasil evaluasi 79, ketuntasan klasikal 85,35 \% dan kategori keaktifan aktif dan sangat aktif pada siklus III. Dilihat dari hasil yang diperoleh, dapat disimpulkan bahwa dengan menerapkan strategi pembelajaran kooperatif tipe cooperative script secara optimal pada perkuliahan program linier dapat meningkatkan aktivitas dan prestasi belajar mahasiswa semester IV program studi pendidikan matematika FKIP Universitas Mataram tahun akademik 2013/2014.
\end{abstract}

Kata Kunci : Cooperative Script, Aktivitas Belajar, Prestasi Belajar, Program Linier

Abstract: The background of the research was the experience of researcher during teaching of Linear Programming topic whereas that the student learning activity was low. It has contribution to less optimum learning outcomes. The purpose of this research was to increase the activity and learning outcomes of the students of fourth semester, mathematics education division, Faculty of Teacher Training and Science Education, Mataram University in the academic year 2013/2014. This classroom action research conducted using 3 cycles. The results obtained in the first cycle were the 63.14 average of the evaluation results, $67.65 \%$ classical completeness and categorized as quite active. The results of the second cycle were 75.74 with $100 \%$ classical completeness and considered as active. In the third cycle showed that the average of the evaluation results was 79 with classical completeness $85.35 \%$, categorized as very active. It can be concluded that the strategy of cooperative learning cooperative script optimally at lectures linear program can increase the activity and achievement of students.

Keyword : Cooperative Script, learning activity, learning achievement, Linier Programing

\section{PENDAHULUAN}

Pendidikan sangat penting peranannya dalam berbangsa dan bernegara, bahkan untuk mengetahui maju mundurnya suatu negara biasa dilihat melalui tingkat kualitas pendidikan masyarakatnya. Dengan memperhatikan hal tersebut, dalam rangka upaya peningkatan kualitas pendidikan pembenahan harus terus menerus dilakukan, baik dari segi materi, metode maupun evaluasi oleh semua pihak yang terkait dalam dunia pendidikan terutama oleh dosen sebagai pengajar. Hal ini sejalan dengan pendapat Hamalik [1] yang menyatakan bahwa salah satu faktor keberhasilan pendidikan suatu bangsa adalah tenaga kependidikan atau sering kita sebut dengan dosen. Dosen merupakan faktor yang mempengaruhi berhasil tidaknya proses belajar, oleh karena itu dosen harus menguasai prinsipprinsip belajar disamping menguasai materi yang akan diajarkan.

Berdasarkan pengalaman peneliti selama mengampu mata kuliah program Linier pada mahasiswa semester IV program studi Pendidikan Matematika FKIP Universitas Mataram, dapat diidentifikasi beberapa masalah yang muncul pada saat proses perkuliahan berlangsung, yaitu: 1) Perhatian mahasiswa terhadap materi yang akan disampaikan masih kurang, hal ini terlihat dari masih ada mahasiswa yang terlambat masuk ruangan, 2) Mahasiswa tidak pernah mau membaca materi yang akan dibahas, meskipun mereka sudah punya buku pegangan dan dosen sudah menginformasikan materi yang akan dibahas pada pertemuan sebelumnya, 3) mahasiswa kesulitan untuk menyimpulkan materi yang sudah dibahas, 4) mahasiswa kesulitan untuk mengaitkan materi yang sudah mereka dapatkan (materi dari mata kuliah prasyarat dengan materi yang akan mereka bahas), 5) Dosen masih kurang kreatif dan inovatif dalam menggunakan metode pembelajaran, dimana dosen hanya menyampaikan materi dan memberikan beberapa latihan soal tanpa adanya kegiatan mahasiswa untuk menemukan konsep dari materi yang sedang dipelajari, selain itu, 6) mahasiswa cenderung bersikap individual, mahasiswa yang mempunyai kemampuan lebih tidak mau membagi pengetahuan pada temannya, sebaliknya mahasiswa yang kemampuannya kurang cenderung diam tidak pernah berusaha untuk bertanya. Hal ini disinyalir menjadi penyebab rendahnya rasa ingin tahu dan motivasi belajar mahasiswa, yang pada 
akhirnya berujung pada rendahnya prestasi belajar dalam hal ini nilai akhir pada mata kuliah program Linier.

Salah satu strategi yang dapat digunakan dosen adalah strategi pembelajaran kooperatif. Pembelajaran koperatif terbukti mampu meningkatkan hasil belajar siswa [2-7]. Salah satu strategi pembelajaran kooperatif adalah tipe Cooperative Script yaitu metode pembelajaran aktif yang menumbuhkan daya kreativitas mahasiswa serta dapat memupuk kerjasama mahasiswa dalam usaha untuk memahami materi. Strategi pembelajaran kooperatif tipe Cooperative Script merupakan salah satu pembelajaran aktif dimana mahasiswa dibentuk menjadi kelompokkelompok kecil dengan masing-masing anggota kelompok mempunyai tanggung jawab yang sama atas keberhasilan kelompoknya dalam memahami materi dan menjawab soal. Metode pembelajaran ini dapat digunakan sebagai alternatif dalam perkuliahan karena metode ini lebih mengacu pada keaktifan belajar mahasiswa, mahasiswa juga dituntut untuk bekerjasama dengan teman-temannya. Dengan metode ini mahasiswa akan lebih bersemangat dalam mengikuti kuliah dan tidak merasa bosan ketika perkuliahan berlangsung di kelas. Berkenaan dengan permasalahan tersebut, maka diperlukan suatu perubahan dan perbaikan terhadap metode perkuliahan yang sering diterapkan selama ini sehingga diharapkan dapat meningkatkan aktivitas dan prestasi belajar mahasiswa.

Cooperative Script adalah strategi pembelajaran yang mengatur interaksi peserta didik seperti ilustrasi kehidupan sosial peserta didik dengan lingkungannya sebagai individu. Misalnya dalam keluarga, kelompok masyarakat, dan masyarakat yang lebih luas. Pada strategi pembelajaran Cooperative Script mahasiswa bekerja secara berpasangan dan secara lisan mengihtisarkan bagian-bagian pada materi pembelajaran yang sedang dipelajari. Pada strategi ini peserta bergantian peran sebagai pembicara dan pendengar. Tugas pembicara adalah menyampaikan konsep-konsep penting dari materi yang dipelajari atau kegiatan yang telah dilakukan. Sedangkan, tugas pendengar adalah menyimak/mengoreksi/menunjukkan ide-ide pokok dengan menghubungkan materi sebelumnya atau dengan materi lainnya [8].

Sintaks langkah-langkah strategi pembelajaran kooperatif tipe Cooperative Script:

1. Menulis topik pembelajaran

2. Menyampaikan tujuan pembelajaran

3. Membagi peserta didik dalam 2 kelompok A dan B. Masing-masing kelompok A dan B beranggotakan 4 orang ( $A-1=4$ orang, $A-2=4$ orang dst, B-1=4 orang, B-2=4 orang dst ). Masing-masing kelompok A dan B mengerjakan kegiatan yang berbeda.

4. Memasangkan satu peserta didik dari kelompok A dengan satu peserta didik dari kelompok B.

5. Dosen bersama peserta didik menetapkan siapa yang pertama berperan sebagai pembicara dan siapa yang berperan sebagai pendengar. Peserta didik yang bertugas sebagai pembicara, menyampaikan hasil kegiatannya kepada peserta didik yang bertugas sebagai pendengar. Selanjutnya, bertukar peran. Peserta didik yang semula sebagai pembicara berperan sebagai pendengar dan yang semula sebagai pendengar berperan sebagai pembicara.

Berdasarkan uraian di atas, dilakukan sebuah penelitian yang dapat mengungkap bagaimana penerapan strategi pembelajaran kooperatif tipe cooperative script pada perkuliahan program linier untuk meningkatkan aktivitas dan prestasi belajar mahasiswa semester IV program studi pendidikan matematika FKIP Universitas Mataram tahun 2013/2014. Dari hasil penelitian ini dapat diidentifikasi bagaimana penerapan strategi pembelajaran kooperatif tipe cooperative script sehingga dapat meningkatkan aktivitas dan prestasi belajar mahasiswa. Adapun tujuan dari penelitian ini adalah untuk meningkatkan aktivitas dan prestasi belajar mahasiswa semester IV Pada mata kuliah Program Linier Program Studi Pendidikan Matematika FKIP Unram Tahun 2013/2014.

\section{METODE PENELITIAN}

\section{A. Setting Penelitian}

Jenis penelitian ini adalah Penelitian Tindakan Kelas (Clasroom Action Research). Menurut Aqib [9] Penelitian tindakan kelas adalah suatu pencermatan terhadap kegiatan yang sengaja dimunculkan, dan terjadi dalam sebuah kelas, dengan tujuan untuk memperbaiki kinerja dosen, sehingga hasil belajar siswa semakin meningkat. Penelitian tindakan kelas ini dilakukan untuk meningkatkan aktivitas dan prestasi belajar mahasiswa pada mata kuliah Program Linier dengan menerapkan strategi pembelajaran kooperatif tipe Cooperative Script.

Penelitian ini dilakukan di Program Studi Pendidikan Matematika FKIP universitas Mataram. Subyek penelitian adalah mahasiswa program studi Pendidikan Matematika Jurusan PMIPA FKIP yang memprogramkan mata kuliah Program Linier tahun akademik 2013 / 2014.

\section{B. Faktor yang diteliti}

Faktor-faktor yang menjadi fokus dalam penelitian ini diantaranya adalah:

1. Faktor mahasiswa, yang diselidiki yaitu peningkatan aktivitas belajar dan prestasi belajar mahasiswa semester IV pada mata kuliah Program Linier Program Studi Pendidikan Matematika FKIP Unram Tahun 2013/2014 dengan menerapkan strategi pembelajaran kooperatif tipe Cooperative Script .

2. Faktor dosen, yang diselidiki adalah kegiatan dosen selama perkuliahan apakah sudah sesuai dengan strategi pembelajaran kooperatif tipe Cooperative Script pada mata kuliah Program Linier.

3. Faktor perkuliahan, yang diselidiki adalah pelaksanaan perkuliahan di dalam kelas apakah 
sudah sesuai dengan Rencana Pelaksanaan Perkuliahan.

\section{Prosedur Penelitian}

Prosedur penelitian tindakan kelas ini dilaksanakan dalam tiga siklus. Setiap siklus dilaksanakan sesuai dengan perubahan yang ingin dicapai. Pada setiap siklus meliputi tahapan - tahapan sebagai berikut :

\section{Tahap Perencanaan Tindakan}

Dalam tahapan perencanaan dilakukan kegiatan sebagai berikut :

a. Membuat rencana pelaksanaan perkuliahan yang sesuai dengan tahap pada strategi pembelajaran kooperatif tipe Cooperative Script.

b. Menyiapkan daftar nama kelompok.

c. Menyiapkan Lembar Kerja Mahasiswa (LKM).

d. Menyiapkan lembar observasi aktivitas dosen dan mahasiswa.

e. Menyiapkan soal tes hasil belajar dan pedoman penskorannya.

\section{Tahap Pelaksanaan Tindakan}

Yang dilakukan pada tahap pelaksanaan tindakan ini yaitu melaksanakan kegiatan belajar mengajar di kelas sesuai dengan rencana pelaksanaan perkuliahan yang telah disusun.

3. Tahap Observasi dan Evaluasi

Pada tahap ini dilakukan observasi terhadap pelaksanaan tindakan menggunakan lembar observasi. Dosen dan mahasiswa diobservasi oleh observer tentang pelaksanaan kegiatan perkuliahan serta aktivitas mahasiswa dalam belajar, apakah metode Cooperative Script sudah dilaksanakan sesuai dengan rencana pelaksanaan perkuliahan yang telah dibuat. Sedangkan untuk tahap evaluasi dilakukan setelah akhir tiap siklus dengan memberikan tes berbentuk essay.

\section{Tahap Refleksi}

Refleksi dilakukan pada akhir siklus. Pada tahap ini, peneliti bersama observer mengkaji pelaksanaan dan hasil yang diperoleh dalam pemberian tindakan tiap siklusnya. Sebagai acuan dalam refleksi ini adalah hasil observasi dan evaluasi. Hasil ini digunakan sebagai dasar untuk memperbaiki serta menyempurnakan perencanaan dan pelaksanaan tindakan pada siklus selanjutnya.

\section{Indikator Kerja}

Yang menjadi indikator keberhasilan dalam penelitian tindakan ini adalah peningkatan aktivitas dan prestasi belajar dengan kriteria sebagai berikut:

1. Aktivitas belajar mahasiswa dikatakan telah meningkat apabila skor aktivitas belajar siswa secara klasikal minimal dalam kategori aktif.

2. Prestasi mahasiswa dikatakan telah meningkat apabila rata-rata skor evaluasi (prestasi) yang diperoleh siswa minimal 56 ( C ) serta mencapai ketuntasan belajar secara klasikal, yaitu $\geq 85 \%$ dari jumlah mahasiswa memperoleh nilai $\geq 56(\mathrm{C})$.

\section{HASIL PENELITIAN DAN PEMBAHASAN \\ A. Hasil Penelitian}

Penelitian ini dilaksanakan dengan menerapkan strategi pembelajaran Cooperative Script pada mata kuliah program linier untuk meningkatkan aktivitas dan prestasi belajar mahasiswa semester IV program studi pendidikan matematika FKIP Universitas Mataram tahun pelajaran 2013/2014 dengan jumlah mahasiswa 34 orang. Penelitian ini berlangsung dalam 3 siklus, masing-masing siklus terdiri dari dua pertemuan. Pada penelitian ini, data prestasi belajar mahasiswa diperoleh dari hasil evaluasi yang dilaksanakan setiap akhir siklus dan data aktivitas mahasiswa selama proses perkuliahan di kelas diperoleh dari lembar observasi.

Kegiatan pada tiap siklus terdiri dari lima tahapan, yaitu perencanaan tindakan, pelaksaan tindakan, tahap observasi, tahap evaluasi dan tahap refleksi. Adapun hasil penelitian ini adalah sebagai berikut. Pada siklus I, kegiatan pembelajaran dilaksanakan dalam dua kali pertemuan dengan masing-masing pertemuan 3 x 50 menit dan materi yang dibahas adalah Metode simpleks untuk kasus maksimum pada pertemuan 1 , metode simpleks untuk kasus minimum dan kasus-kasus khusus pada pertemuan 2. Berikut ini akan dipaparkan mengenai data hasil penelitian pada siklus 1 (Tabel 1).

Pada siklus II, kegiatan pembelajaran juga dilaksanakan dalam dua kali pertemuan dengan masing-masing pertemuan 3 x 50 menit. Materi yang disampaikan pada siklus II adalah tentang dualitas, yaitu Menyelesaikan masalah dual pada pertemuan 1 dan Hubungan Dual dengan Primal pada pertemuan 2. Adapun hasil yang diperoleh pada siklus II ini dapat dilihat pada Tabel 2 .

Tabel 1. Data Aktivitas Belajar dan Hasil Evaluasi siklus 1

\begin{tabular}{|c|c|c|}
\hline Siklus 1 & Skor Aktivitas Mahasiswa & Kategori \\
\hline PP Pertemuan 1 & 10,99 & Cukup Aktif \\
\hline PP Pertemuan 2 & 12,34 & Aktif \\
\hline Rata - Rata Hasil Evaluasi & 63,14 & \\
\hline Ketuntasan Klasikal & $67,65 \%$ & \\
\hline
\end{tabular}


Tabel 2. Data Aktivitas Belajar dan Hasil Evaluasi siklus 2

\begin{tabular}{lcc}
\hline \multicolumn{1}{c}{ Siklus 2 } & Skor Aktivitas Mahasiswa & Kategori \\
\hline PP Pertemuan 1 & 13,66 & Aktif \\
PP Pertemuan 2 & 15,00 & Aktif \\
\hline Rata - Rata Hasil Evaluasi & & \\
\hline Ketuntasan Klasikal & & 75,74 \\
\hline
\end{tabular}

Tabel.3. Data Aktivitas Belajar dan Hasil Evaluasi siklus 3

\begin{tabular}{lcc}
\hline \multicolumn{1}{c}{ Siklus 3 } & Skor Aktivitas Mahasiswa & Kategori \\
\hline PP Pertemuan 1 & 14,66 & Aktif \\
PP Pertemuan 2 & 16,67 & Sangat Aktif \\
\hline Rata - Rata Hasil Evaluasi & \multicolumn{3}{c}{79} \\
\hline Ketuntasan Klasikal & $85,35 \%$ \\
\hline
\end{tabular}

Tabel 4. Hasil penelitian Siklus 1 sampai 3

\begin{tabular}{rcccc}
\hline $\begin{array}{l}\text { Siklus } \\
\text { Ke- }\end{array}$ & $\begin{array}{l}\text { Rata - rata Hasil } \\
\text { Evaluasi }\end{array}$ & $\begin{array}{c}\text { Ketuntasan Belajar } \\
\text { Klasikal }\end{array}$ & $\begin{array}{c}\text { Aktivitas } \\
\text { Belajar }\end{array}$ & Kategori \\
\hline 1 & 63,14 & $67,65 \%$ & 10,99 & $\begin{array}{c}\text { Cukup Aktif } \\
\text { Aktif }\end{array}$ \\
& & & 12,34 & Aktif \\
2 & 75,74 & $100 \%$ & 13,66 & Aktif \\
& & & 15,00 & Aktif \\
& 79 & $85,35 \%$ & 14,66 & Sangat Aktif \\
\hline
\end{tabular}

Selanjutnya Siklus III materi yang disampaikan adalah tentang masalah transportasi. Pada siklus ini pembelajaran dilaksanakan dua kali pertemuan masing-masing pertemuan 3 x 50 menit, pada pertemuan 1 materinya tentang solusi awal model transportasi dan pertemuan 2 tentang solusi optimum model transportasi. Hasil yang diperoleh dari pelaksanaan siklus III dapat dilihat pada Tabel 3. Dari hasil penelitian diatas dapat dilihat bahwa indikator kerja yang telah ditetapkan pada penelitian ini sudah tercapai pada siklus II. Tetapi penelitian tetap dilanjutkan pada siklus III, hal ini disebabkan karena masih ada materi yang harus disampaikan dan terlihat ada beberapa indikator yang belum terlaksana dengan baik.

\section{B. Pembahasan}

Penelitian tindakan kelas yang dilakukan dalam 3 siklus ini bertujuan untuk meningkatkan aktivitas dan prestasi belajar mahasiswa $\mathrm{S} 1$ pendidikan matematika FKIP Universitas Mataram tahun akademik 2013/2014 pada matakuliah Program Linier. Secara ringkas hasil penelitian ini dapat dilihat pada Tabel 4. Berdasarkan hasil penelitian yang dapat dilihat pada tabel 3.4 terlihat bahwa selalu terjadi peningkatan pada setiap siklus baik aktivitas maupun rata-rata hasil evaluasinya. Hal ini disebabkan karena selalu ada upaya perbaikan tindakan pada setiap pertemuan sesuai dengan kekurangan yang terlihat pada pertemuan sebelumnya.
Pada siklus I rata-rata hasil evaluasi yang diperoleh adalah 63,14, ketuntasan klasikal 67,65 \% dan aktivitas berada dalam kategori cukup aktif dan aktif. Hal ini menunjukkan bahwa hasil yang diperoleh belum mencapai indikator yang diharapkan, sehingga perlu dilanjutkan siklus II sebagai upaya untuk memperbaiki kekurangan pada siklus I. Adapun kekurangan yang nampak pada siklus I adalah mahasiswa masih terlihat kebingungan dalam menjalankan perannya masing-masing, sehingga banyak waktu yang digunakan untuk mengarahkan mahasiswa agar menjalankan perannya dengan baik. Masih banyak mahasiswa yang belum memanfaatkan sumber belajar secara maksimal, dalam hal ini tidak lebih dari $50 \%$ mahasiswa yang membaca dengan serius buku pegangan yang sudah diinformasikan diawal kuliah, hal ini menyebabkan waktu yang mereka gunakan untuk mengerjakan LKS lebih banyak dari yang direncanakan. Selain itu, pada siklus I nampak bahwa sebagian besar mahasiswa tidak fokus saat memperhatikan temannya (pembicara) menjelaskan, hal ini disebabkan karena mahasiswa belum terbiasa dengan strategi pembelajaran yang diterapkan.

Pada siklus II dilakukan perbaikan-perbaikan sesuai dengan kekurangan yang terjadi pada siklus I, oleh sebab itu terlihat ada peningkatan hasil evaluasi menjadi 75,74 dengan ketuntasan belajar mencapai $100 \%$. Hal ini menunjukkan bahwa indikator yang ditetapkan sudah tercapai, akan tetapi walaupun 
demikian penelitian masih terus dilanjutkan kesiklus berikutnya sesuai dengan perencanaan awal. Selain itu, peneliti menganggap bahwa penelitian perlu dilanjutkan agar mahasiswa terbiasa untuk mengungkapkan ide dengan baik dan menjadi pendengar yang mampu mengolah apa yang disampaikan temannya. Selain itu, diharapkan agar mahasiswa terbiasa untuk belajar mandiri dengan mengoptimalkan pemanfaatan sumber belajar yang ada.

Pada siklus III terlihat aktivitas belajar mahasiswa berada pada kategori sangat aktif, hal ini menunjukkan bahwa pelaksanaan pembelajaran sudah terlaksana dengan optimal dan pembelajaran sudah didominasi oleh mahasiswa. Akan tetapi ketuntasan belajar klasikal pada siklus III mengalami penurunan, walaupun demikian ketuntasan yang dicapai sudah lebih dari $85 \%$. Penurunan ketuntasan terjadi karena materi yang disampaikan pada siklus III adalah materi baru sehingga pada tahun-tahun sebelumnya materi tersebut belum ada, bagi mahasiswa lama yang mengulang mereka terlihat kesulitan untuk mengikuti cara belajar adik tingkatnya. Hal ini menyebabkan ketuntasan tidak mencapai $100 \%$ dan mahasiswa yang tidak tuntas adalah mahasiswa yang mengulang.

Dengan demikian dapat dikatakan bahwa dengan menerapkan strategi pembelajaran kooperatif tipe cooperative script secara optimal pada perkuliahan program linier dapat meningkatkan aktivitas dan prestasi belajar mahasiswa semester IV program studi pendidikan matematika FKIP Universitas Mataram tahun akademik 2013/2014.

\section{KESIMPULAN}

Berdasarkan hasil penelitian dan pembahasan diatas, maka dapat disimpulkan bahwa dengan menerapkan strategi pembelajaran kooperatif tipe cooperative script secara optimal pada perkuliahan program linier dapat meningkatkan aktivitas dan prestasi belajar mahasiswa semester IV program studi pendidikan matematika FKIP Universitas Mataram tahun akademik 2013/2014.

Adapun langkah-langkah yang dilakukan dalam menerapkan strategi pembelajaran kooperatif tipe cooperative script ini adalah : Menuliskan tujuan yang ingin dicapai, bekerja dalam kelompok, bekerja berpasangan, menjalankan peran sebagai pasangan pembicara dan pendengar, bertukar peran dan menyimpulkan.

\section{DAFTAR PUSTAKA}

[1] Hamalik, O. 2007. Psikologi Belajar dan Mengajar. Bandung: Sinar Baru Algesindo.

[2] Azizah, N. 2016. Pengembangan LKS dan penerapannya dalam pembelajaran kooperatif tipe STAD untuk meningkatkan aktivitas dan hasil belajar kimia siswa kelas XI IPA SMAN 1 Batulayar tahun pelajaran 2015/2016. Jurnal Pijar Mipa, 11(1).

[3] Wijayanti, A. 2016. Implementasi model pembelajaran kooperatif tipe tgt sebagai upaya meningkatkan pemahaman konsep fisika dasar mahasiswa pendidikan IPA. Jurnal Pijar Mipa, 11(1).

[4] Raksun, A. 2009. Implementasi pembelajaran kooperatif untuk meningkatkan motivasi dan hasil belajar mahasiswa program studi pendidikan fisika fkip universitas mataram pada matakuliah biologi dasar. Jurnal pijar MIPA, 4(1).

[5] Aryana, I. G. M. R., Al Idrus, A., \& Harjono, A. 2015. Pengaruh model pembelajaran kooperatif nht dan stad terhadap hasil belajar sikap siswa sma negeri 2 gerung. Jurnal pijar MIPA, 10(2).

[6] Yulianti, R., Muntari, M., \& Haris, M. 2015. Pengaruh model pembelajaran kooperatif tipe two stay two stray (tsts) dengan pendekatan brainbased learning terhadap hasil belajar kimia materi pokok struktur atom dan sistem periodik unsur pada siswa kelas X SMAN 1 Kediri. Jurnal pijar MIPA, 10(1).

[7] Irzi, R. H., Sripatmi, S., \& Hapipi, H. 2015. Penerapan model pembelajaran kooperatif tipe snowball throwing pada pembelajaran segiempat untuk meningkatkan aktivitas dan prestasi belajar siswa SMPN 1 lingsar kelas VII-1 tahun pelajaran 2012/2013. Jurnal Pijar MIPA, 10(1).

[8] Chotimah H., dan Dwitasari Y., 2009. Strategi strategi Pembelajaran untuk Penelitian Tindakan Kelas. Malang : Surya Pena Gemilang.

[9] Aqib, Z. 2009. Penelitian Tindaka Kelas. Bandung: CV Yrama Widya.

[10] Nurkancana, W dan P. P. N. Sunartana. 1990. Evaluasi Hasil Belajar. Surabaya: Usaha Nasional.

[11]Djamarah, S.B. 1994. Prtestasi Belajar dan kompetensi Guru. Surabaya : Usaha Nasional.

[12] Tim Penyusun, 2009. Kurikulum program studi Pendidikan Matematika. Pendidikan Matematika FKIP Unram. 